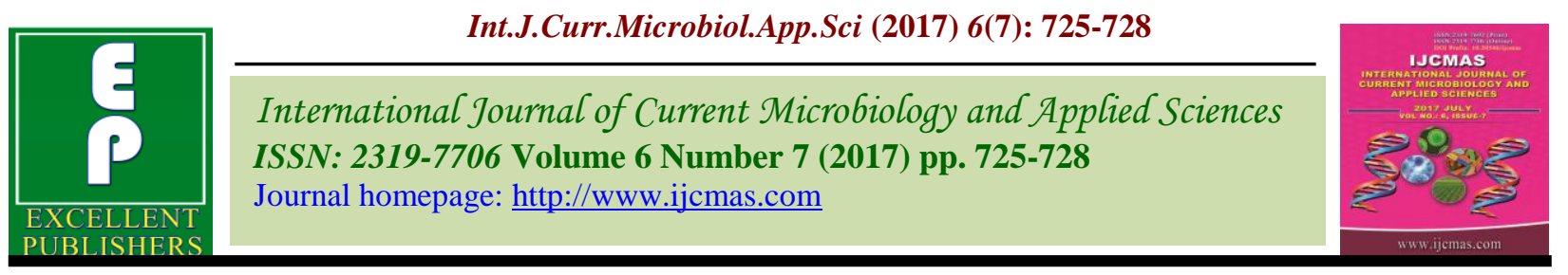

Original Research Article

https://doi.org/10.20546/ijcmas.2017.607.090

\title{
Agronomic Evaluation of Promising Pre-Release Inter Specific Cotton Hybrids
}

\author{
Harphool Meena*, P.K.P. Meena and Bheru Lal Kumhar \\ Agricultural Research Station, Ummedganj Farm Agriculture University, Kota-324001, \\ Rajasthan, India \\ *Corresponding author
}

\begin{tabular}{|c|c|}
\hline & A B S T R A C T \\
\hline $\begin{array}{l}\text { K e y w o r d d s } \\
\text { Inter specific } \\
\text { cotton, Plant } \\
\text { geometry, Seed } \\
\text { cotton yield and } \\
\text { fertility levels. }\end{array}$ & $\begin{array}{l}\text { Field experiment was conducted at Agricultural Research Station, Borwat Farm, Banswara } \\
\text { during kharif - } 2011 \text { to find out the optimum plant geometry and fertility levels for inter } \\
\text { specific cotton hybrids with three cotton hybrids (USHB-25,PSCHB-901 and DCH-32), } \\
\text { two plant geometries }(90 \times 60 \text { and } 90 \times 45 \mathrm{~cm} \text { ) and three fertility levels }(75,100 \text { and } 125 \% \\
\text { RDF). Sowing of USHB- } 25 \text { cotton hybrid gave significantly higher seed cotton yield } \\
\left(2354 \mathrm{~kg} \mathrm{ha}^{-1}\right) \text { over PSCHB-901. The maximum seed cotton yield }\left(2208 \mathrm{~kg} \mathrm{ha}^{-1}\right) \text { was } \\
\text { observed under plant geometry of } 90 \times 60 \mathrm{~cm} \text { than wider plant geometry of } 90 \times 45 \mathrm{~cm} \text {. }\end{array}$ \\
\hline Article Info & Though, yield attributing parameters such as bolls plan $^{-1}$ and boll weight were statically \\
\hline $\begin{array}{l}\text { Accepted: } \\
\text { 14 June } 2017 \\
\text { Available Online: } \\
10 \text { July } 2017\end{array}$ & $\begin{array}{l}\text { Among fertility levels, similar seed cotton yield was recorded with the application of } 100 \\
\% \text { RDF }\left(2178 \mathrm{~kg} \mathrm{ha}^{-1}\right) \text { and } 125 \% \text { RDF }\left(2235 \mathrm{~kg} \mathrm{ha}^{-1}\right) \text { but both were significantly better } \\
\text { than that of } 75 \% \text { RDF and plant geometry } 90 \times 60 \mathrm{~cm}^{2} \text { seemed to be ideal for inter specific } \\
\text { hybrid cotton for realizing higher productivity under the specific agro climatic zone IV b. }\end{array}$ \\
\hline
\end{tabular}

\section{Introduction}

Cotton, Gossypium hirsutum L., is one of the most important fibre crops playing a key role in economic and social affairs of the world. It is a soft fibre that grows around the seeds of the cotton plant Gossypium spp., a shrub native to tropical and subtropical regions around the world, including the Americas, India, and Africa. The fibre is most often spun into thread and used to make a soft, breathable textile, which is the most widely used natural-fibre cloth in clothing today. It is generally believed that the first cultivation of cotton was in India, though it grew wild in several locations around the world. People living in Egypt's Nile Valley and across the world in Peru were also familiar with cotton
(Deng et al., 2004). Plant geometry having greater importance in cotton cultivation. Bt cotton crop may be producing excessive vegetative growth at wider plant geometry and excessive reproductive growth at close plant geometry. However, numerically lower monopodial with closer plant geometry and lower sympodial with wider plant geometry were observed indicating more period under vegetative growth with wider spacing (Buttar and Singh, 2006). Closer plant geometry also recorded higher seed cotton yields (Sankaranarayanan et al., 2004).

Nutrient management in cotton is complex due to simultaneous production of vegetative 
and reproductive structures during the active growth phase. The nutrient supplementation period can be increased, which provides long time from square formation to boll development. Hence, nutrient requirement during critical stages can be better met. Need for major nutrients especially nitrogen and potassium rises dramatically when bolls are set on the plants which are major sinks for potassium and high concentrations of potassium are required to maintain sufficient water pressure (water potential) for fibre elongation. Most of the cotton growing soils are losing their fertility level due to continuous mining of the nutrients from the soil (Blaise and Prasad, 2005). Thus an efficient nutrient management plan is the key in the light of the negative nutrient balances. Nutrient management in Bt-cotton is a better challenge to boost production and productivity.

Cultivar selection, a key management component in any cropping system, is even more critical in various crop geometry of cotton production. While high yield potential is a predominant consideration, maturity, plant size, the transgenic present, and fiber properties are also major factors to consider (Jones, 2001). The maximum exploitation of these genotypes can be achieved only after determining their optimum planting densities in comparison to recommended cotton varieties. In general, it was observed that lower plant densities produces high values of growth and yield attributes per plant, but yield per unit area was higher with higher plant densities (Sharma et al., 2001).

\section{Materials and Methods}

An experiment was conducted during kharif 2011 at Agricultural Research Station, Borwat Farm, Banswara. The eighteen treatment combinations comprised of three cotton hybrids (USHB-25, PSCHB-901 and DCH-
32) in main plot, two plant geometries $(90 \mathrm{x}$ 60 and $90 \times 45 \mathrm{~cm}$ ) in sub plot and three fertility levels $(75,100$ and $125 \% \mathrm{RDF})$ in sub-sub plot under split plot design with four replications. Experimental field was well prepared by two ploughing followed by harrowing and cultivator and one planking for uniform leveling were performed for sowing of cotton. The soil was medium in available nitrogen (247 kg/ha), phosphorus (48.20 $\mathrm{kg} / \mathrm{ha}$ ) and high in available potassium (328 $\mathrm{kg} / \mathrm{ha}$ ) during the crop season. The crop was sown in last week of May by dibbling 2-3 seeds per hills and full dose of phosphorus and potash were applied before sowing, while nitrogen dose was given in two splits i.e. first half at the time of thinning and remaining half at flowering stage. All production and protection measures were applied as per package of the zone IV b of Rajasthan.

\section{Growth}

Data shows that the sowing of inter specific hybrid cotton, among the cotton hybrids the USHB-25 was proved superior over PSCHB901. Cotton hybrid USHB-25 gave higher plant height $(109.50 \mathrm{~cm})$, monopodial branches plant $^{-1}$ (1.28), sympodial branches plant $^{-1}$ (20.06) as compared to PSCHB-901, but it was found at par with DCH-32 cotton hybrid plant height $(108.60 \mathrm{~cm})$, monopodial branches plant ${ }^{-1}$ (1.26), and sympodial branches plant ${ }^{-1}$ (19.85). The wider plant spacing 90 x $60 \mathrm{~cm}$ gave significantly higher plant height $(113.09 \mathrm{~cm})$, monopodial branches plant $^{-1}$ (1.17) and sympodial branches plant ${ }^{-1}(19.20)$ over sowing at $90 \mathrm{x}$ $45 \mathrm{~cm}$ plant spacing plant height $(107.20 \mathrm{~cm})$, monopodial branches plant $^{-1}(1.08)$ and sympodial branches plant $^{-1}$ (16.31). Significantly increase the growth of cotton with the increasing of fertility levels, application of $100 \% \mathrm{RDF}$ and $125 \% \mathrm{RDF}$ were found at par with each other. The maximum plant height $(109.64 \mathrm{~cm})$, 
monopodial branches plant $^{-1}$ (1.17) and sympodial branches plant $^{-1}$ (19.13) were observed under application of $100 \% \mathrm{RDF}$ over application of $75 \% \mathrm{RDF}$ plant height $(103.98 \mathrm{~cm})$, monopodial branches plant ${ }^{1}(1.05)$ and sympodial branches plant $^{-1}$ (16.12). Height increase could be due to competition for solar radiation, water and nutrient uptake among the plants. Besides leaf production was associated with plant height changes (Gao and Jein, 1989).

\section{Yield attributes}

Cotton hybrid USHB-25 gave higher bolls plant $^{-1}$ (27.20), boll weight (4.35) over PSCHB-901 cotton hybrid bolls plant ${ }^{-1}$ (22.09), boll weight (3.86), but it was found at par with DCH-32 cotton hybrid. The wider plant spacing $90 \times 60 \mathrm{~cm}$ gave significantly higher bolls plant ${ }^{-1}$ (25.23), boll weight (4.31) over sowing at $90 \times 45 \mathrm{~cm}$ plant spacing bolls plant $^{-1}$ (20.45), boll weight (3.98). Application of $100 \% \mathrm{RDF}$ and $125 \% \mathrm{RDF}$ were found at par with each other. The maximum bolls plant $^{-1}$ (24.02), boll weight (4.00) were observed under application of $100 \% \mathrm{RDF}$ over application of $75 \%$ RDF bolls plant ${ }^{-1}$ (19.16), boll weight (3.69). The difference between a narrow row and a wide row was not significant on yield but a wider row may facilitate intercultural and light interception but this advantage is seldom translated into improvements in yield Nehra and Kumawat, 2003 and Sharma et al., 2001.

Table.1 Effect of plant geometry and fertility levels on growth, Yield attributes and seed cotton yield of inter specific hybrid cotton

\begin{tabular}{|c|c|c|c|c|c|c|}
\hline Treatment & $\begin{array}{l}\text { Plant height } \\
\text { (cm) }\end{array}$ & $\begin{array}{c}\text { Monopodial } \\
\text { branches / plant }\end{array}$ & $\begin{array}{l}\text { Sympodial } \\
\text { branches / } \\
\text { plant }\end{array}$ & $\begin{array}{l}\text { Bolls } \\
\text { / plant }\end{array}$ & $\begin{array}{c}\text { Boll } \\
\text { weight } \\
\text { (g) }\end{array}$ & $\begin{array}{c}\text { Seed cotton } \\
\text { yield } \\
(\mathrm{kg} / \mathrm{ha})\end{array}$ \\
\hline \multicolumn{7}{|l|}{ Variety } \\
\hline USHB-25 & 109.50 & 1.28 & 20.06 & 27.20 & 4.35 & 2354 \\
\hline PSCHB-901 & 102.23 & 1.10 & 15.89 & 22.09 & 3.86 & 2034 \\
\hline DCH-32 & 108.60 & 1.26 & 19.85 & 26.54 & 4.29 & 2298 \\
\hline SEm \pm & 1.69 & 0.04 & 0.45 & 1.28 & 0.13 & 72 \\
\hline $\mathrm{CD}(\mathrm{p}=0.05)$ & 5.16 & 0.13 & 1.27 & 3.90 & 0.38 & 208 \\
\hline \multicolumn{7}{|c|}{ Plant geometry } \\
\hline $90 \times 60 \mathrm{~cm}$ & 113.09 & 1.17 & 19.20 & 25.23 & 4.31 & 2208 \\
\hline $90 \times 45 \mathrm{~cm}$ & 107.20 & 1.08 & 16.31 & 20.45 & 3.98 & 1895 \\
\hline SEm \pm & 1.71 & 0.03 & 0.32 & 1.10 & 0.07 & 69 \\
\hline $\mathrm{CD}(\mathrm{p}=0.05)$ & 5.29 & 0.08 & 1.02 & 3.41 & 0.24 & 212 \\
\hline \multicolumn{7}{|l|}{ Fertility levels } \\
\hline $75 \%$ RDF & 103.98 & 1.05 & 16.12 & 19.16 & 3.69 & 1904 \\
\hline $100 \%$ RDF & 109.64 & 1.17 & 19.13 & 24.02 & 4.00 & 2178 \\
\hline $125 \% \mathrm{RDF}$ & 112.08 & 1.18 & 20.14 & 26.47 & 4.08 & 2235 \\
\hline SEm \pm & 1.78 & 0.04 & 0.48 & 1.12 & 0.10 & 81 \\
\hline $\mathrm{CD}(\mathrm{p}=0.05)$ & 5.52 & 0.11 & 1.39 & 3.40 & 0.28 & 239 \\
\hline
\end{tabular}

\section{Seed cotton yield}

Sowing of cotton hybrids USHB-25 and DCH-32 were found at par with each other in terms of seed cotton yield. The maximum seed cotton yield $\left(2354 \mathrm{~kg} \mathrm{ha}^{-1}\right)$ was observed by sowing of USHB-25 over sowing of PSCHB-901 seed cotton yield (2034 kg ha $\left.{ }^{-1}\right)$. Significantly higher seed cotton yield (2208 $\mathrm{kg} \mathrm{ha}^{-1}$ ) was recorded under sowing at $90 \times 60$ $\mathrm{cm}$ wider plant spacing over sowing at closer plant spacing at $90 \times 45 \mathrm{~cm}$ seed cotton yield 
(1895 $\mathrm{kg} \mathrm{ha}^{-1}$ ). Significantly increasing the seed cotton yield with the increasing of fertility levels, application of $100 \%$ RDF and $125 \% \mathrm{RDF}$ were found at par with each other. The maximum seed cotton yield (2178 $\mathrm{kg} \mathrm{ha}^{-1}$ ) was found under application of 100 $\%$ RDF over application of $75 \%$ RDF seed cotton yield (1904 kg ha-1). The increase in seed cotton yield per plant was observed in plant geometries $90 \mathrm{~cm} \times 60 \mathrm{~cm}$ than $90 \mathrm{~cm} \mathrm{x}$ $45 \mathrm{~cm}$. This might be due to better aeration, adequate interception of light and lesser competition for available nutrient and moisture, which have resulted in synthesis of higher photosynthates and in turn helped to produce higher seed cotton yield per plant under wider intra row spacing. Similar results were reported by Sankaranarayanan et al., (2004) and Buttar and Singh (2007).

Based on the results it was concluded that variety USHB-25 over sowing of PSCHB901. Significantly higher seed cotton yield recorded under sowing at $90 \times 60 \mathrm{~cm}$ wider plant spacing over sowing at closer plant spacing at $90 \times 45 \mathrm{~cm}$.

\section{References}

Blaise, D. and Prasad, R. Integrated plant nutrient supply: An approach to sustained cotton production. Indian $J$. Fert., 1: 37-46 (2005).

Buttar, G.S. and Singh, Paramjit. Performance of Bt cotton hybrids at different plant populations in South Western region of Punjab. J. Cotton Res. Dev., 20(1):9798 (2006).
Deng, X. P., Shan, L., Zhang, H.P. and Turner, N.C. (2004) Improving Agricultural Water Use Efficiency in Arid and Semiarid Areas of China. New Directions for a Diverse Planet. Proceeding of the 4th International Crop Science Conference, Brisbane.

Gao, Q and Jein, J.S. 1989. A study of cultivation model for high quality and yield in cotton using leaf observation. The relationship between leaf order and organ formation in cotton. Journal of Nanjing Agriculture University. 4: 1-8.

Jones M.A., 2001 - Evaluation of ultranarrow row cotton in South Carolina. p. 522524. In: Proc. Beltwide Cotton Conf., Anaheim, CA. 9-13 Jan. 2001.

Nehra, P.L. and Kumawat, P.D. 2003. Response of hirsutum cotton varieties to spacing and nitrogen levels. J. Cotton Res. Dev., 17(1): 41-42.

Sankarnarayanan, K.P., Nalayini and Praharaj, C.S. Agronomic requirements of Bt cotton hybrid in relation to plant density and fertilizer requirement. Intern. Symp. On Strategies for sustainable cotton production - A global vision, 2. Crop Production, 23-25 November, 2004, UAS, Dharwad, 248 p (2004).

Sharma, J.K., Upadhayay, Mishra, U.S., Khamparia, S.K., and Andloi, K.C.M. 2001.Effect of spacing and fertility levels on growth and yield of hirsutum genotypes. J. Cotton Res. Dev., 15(2): 151-153.

\section{How to cite this article:}

Harphool Meena, P.K.P. Meena and Bheru Lal Kumhar. 2017. Agronomic Evaluation of Promising Pre-Release Inter Specific Cotton Hybrids. Int.J.Curr.Microbiol.App.Sci. 6(7): 725728. doi: https://doi.org/10.20546/ijcmas.2017.607.090 